\title{
Spaces for Domestic Devotion in the Noble Residences of Palermo in the Age of Catholic Reform
}

\author{
Valeria Viola
}

In the mid-eighteenth century, Francesco Maria Emanuele Gaetani, Marquis of Villabianca (1720-1802), acknowledged that in Palermo the prestige and distinction of a palace had depended on the presence of 'crenellations, turrets, columns, courtyards and private churches.' ${ }^{1}$ He was referring to the Royal Palace which the Normans began constructing in 1132, and to medieval fortified houses, whose private chapels were notable for their sizable dimensions. ${ }^{2}$ The Marquis, despite being a valuable source of information on the period, is known to have been a conservative voice from the upper echelons of society, perpetually worried by the evolving world around him. He complained that the custom of erecting great private oratories was vanishing, because of the new, and in his words 'mal consigliata' (erroneous) custom of allowing domestic chapels inside rooms. ${ }^{3}$ His words, however, prove that devotional spaces albeit reduced in size - were still considered necessary to complete a noble home in Palermo.

Pending the conclusion of research that is still underway, this paper provides an overview of chapels and oratories in the noble residences of Palermo in the post-Tridentine age. It asserts that the pervasive and enduring role of religion was reflected in the architecture of private devotional spaces. ${ }^{4}$ This paper sheds light on the continuous re-negotiation of the boundaries between

1 'La distinzione anticamente de' nostri palazzi civici consisteva ne' merli, colonne, corti e chiese private complesse in essi'. These notes by the Marquis of Villabianca come from his "Opuscoli Palermitani", an eighteenth-century manuscript partly transcribed in Mazzè A. (ed.), I Palazzi regi di Palermo, monasteri e cappelle private (Palermo: 1991) 94.

2 Mazzè (ed.), I Palazzi regi di Palermo 96.

3 Ibid., 97 .

4 Because archival sources are currently under investigation, this paper mainly takes advantage of published works that shed light on the topic, as well as analysis of some extant examples of chapels and oratories. In addition, to gain an idea of Sicilian aristocratic practices, the paper draws on both earlier sources and some recent interviews conducted with the heirs of those noble families who still own historical residences (or parts of them) and still preserve memories of the devotional use of these spaces.

(C) VALERIA VIOLA, 2019 | DOI:10.1163/9789004375871_005

This is an open access chapter distributed under the terms of the prevailing CC-BY-NC-ND License at the time of publication. 
religious and secular spheres in the domestic environment. A comparison of oratories in villas and chapels located in urban and rural palaces suggests that rural oratories were more closely intertwined with the development of links between aristocratic families and local populations, while urban chapels were smaller and more private.

Two premises should be established before proceeding. The first relates to the issue of terminology: devotional spaces for laypeople are described in contemporary sources as either 'chapels' or 'oratories' (or even 'private churches', as above) without distinction, which is confusing for the modern reader. This confusion, however, has a historical basis, because the conception and the use of these private spaces seems to have been indistinct until the sixteenth century, when the Council of Trent laid down rules in an attempt to define these sacred spaces. ${ }^{5}$ Nonetheless, the general term 'cappella' (chapel) has also lingered in everyday language to define some of these rooms, especially in palaces. ${ }^{6}$ This can partly be explained by the fact that the term generally identifies a relatively small architectural space dedicated to worship, either in a church or in another architectural context, whilst the word oratory is commonly used for a larger and, specifically, independent buildings. Oratories are therefore generally easily identifiable, but it is not always so easy to discern devotional spaces inside urban residences - where they might be limited to a niche, but could expand into the surrounding domestic space when needed. ${ }^{7}$

5 The Council of Trent did not directly address the issue of private oratories. An indirect reference to them is expressed within the conciliar decree De observandiis (23rd Session, 17 th October 1562), when, listing the necessary precautions to avoid an attitude of irreverence ('ut irreverentia vitetur'), correct behaviour in domestic oratories was described; further on, the document required that the Eucharist could only be celebrated in oratories which were exclusively dedicated to divine worship, had been visited by ordinaries, and approved by pontifical authority. However, the matter was not settled definitively until 1917 when the Church's preference for the word 'oratorio' (oratory) to define these spaces was established in canon law, and a distinction made between public, semi-public, and private oratories. Codex Iuris Canonici (CIC, 1917, can. 1188-1196). However, the CIC of 1983 removed the second category of 'semi-public oratory', the most difficult to identify, while the private oratory remains 'locus divino cultui, in commodum unius vel plurium personarum physicarum, de licentia Ordinarii loci destinatus' (CIC, 1983, can. 1226), i.e. 'a place addressed by the bishop's allowance to the cult, for the use of one or more people'.

6 The term 'cappella' is constantly preferred in archival inventories of the seventeenth and eighteenth centuries, while the term 'oratorio' is more frequent in Diocesan documents of the same period.

7 As Susan Gal argues in a different context, 'the issue is not one of instable or fuzzy boundaries. Rather, the intertwining public and private is created by practices that participants understand as re-creations of the dichotomy. The same can be said for the opposition of sacred and secular. Gal S., "A Semiotics of the Public/Private Distinction", Differences. A Journal of Feminist Cultural Studies 13, 1 (2002) 84. 
Therefore, here the term oratory is used only if the room is identifiable as a completely or largely independent construction; otherwise, the term chapel will be employed, trying in all cases to describe any spaces as accurately as possible in architectural terms.

Secondly, despite the scholarly attention currently being paid to the theme of domestic devotion in the early modern period, very little has yet been written which focuses specifically on the south of Italy. ${ }^{8}$ The situation is no better when one considers local scholarship that focuses more on elaborate reception rooms rather than on private spaces, and least of all on chapels. ${ }^{9}$ Furthermore, few rooms and pieces of furniture have survived untouched within private palaces. Even the offices of bodies charged with the preservation of historic architecture do not have records of these rooms. Family archives, if they are still available, too often lie hidden in dusty attics. There is a real risk that, as little scholarly attention is being paid to this subject, the heritage itself is gradually being lost. Partly as a result of the dearth of interest, this attempt to shed light

8 The current debate is overwhelmingly focused on northern Europe and often limited to northern and central Italy (e.g. Smith J.M.H., "Material Christianity in the Early Mediaeval Household", in Doran J. - Methuen C. - Walsham, A. (eds.), Religion and the Household, Studies in Church History 50 (2014) 23-46; Campbell E.J. - Miller S.R. - Consavari E.C. (eds.), The Early Modern Italia Domestic Interior, 1400-1700: Objects, Spaces, Domesticities (Farnham: 2013); Hirschboeck M., Florentinische Palastkapellen unter den ersten Medici-Herzögen (15371609). Verborgene Orte frommer Selbstdarstellung und konfessioneller Identität (Berlin: 2011); Cavallo S. - Evangelisti S. (eds.), Domestic Institutional Interiors in Early Modern Europe (Aldershot and Burlington: 2009); Anderson C.C., "The Material Culture of Domestic Religion in Early Modern Florence", Ph.D. dissertation (University of York: 2007); Morse M.A., "The Arts of Domestic Devotion in Renaissance Italy: the case of Venice", Ph.D. dissertation (University of Maryland: 2006); Mattox P.E., "The Domestic Chapel in Renaissance Florence, 1400-1550", Ph.D. dissertation (Yale University: 1996). Yet recently, some scholars have noted that 'the preoccupation with this "golden triangle" of Florence, Rome and Venice has skewed our view of the period, especially when it comes to consideration of the lives of ordinary families', see the Introduction in Corry M. - Howard D. - Laven M. (eds.), Madonnas \& Miracles. The Holy Home in Renaissance Italy (London: 2017) 7. See also Irene Galandra Cooper's essay in this volume, 220-243.

9 Local interest in private residences in Palermo has grown slowly, as many monographs prove: Grasso S., "Il Palazzo Butera a Palermo: acquisizioni documentarie" Antichità Viva 12 no.5 (1980) 33-38; Aricò N. et alia, Abitare a Palermo. Due Palazzi e la loro storia tra Cinquecento e Ottocento (Cinisello Balsamo: 1983); Scaduto F., Architettura e committenza nella Palermo del Cinquecento: il Palazzo Castrone di via Toledo (Palermo: 2002); Piazza S., Il palazzo Valguarnera-Gangi a Palermo (Palermo: 2004); Marafon Pecoraro M. - Palazzotto P. Vesco M., Palazzo Alliata di Pietratagliata tra tardogotico e neostili. Archivi, cantieri, protagonisti a Palermo (Palermo: 2013); Zalapì A. - Maurizio Rotolo M., Palazzo Comitini (Palermo: 2011). Yet none of these shows any concern for devotional spaces. 
on the situation in Palermo will necessarily be partial, because many hypotheses are still to be confirmed.

From the start of its life as a city until its unification with the rest of Italy in 1861, Palermo's urban density gradually increased, saturating the spaces that today mark its historic centre. During this long process, the so-called 'golden century' of Palermo's religious and residential architecture took place from the end of the seventeenth to the early eighteenth century. ${ }^{10}$ Throughout this period religious orders competed in building wonderful churches and convents and the aristocracy constructed breath-taking residences, overwhelming the medieval parts of the city with imposing palaces and filling the surrounding areas with sumptuous villas.

At the end of the sixteenth century royal policy pushed the aristocracy towards the countryside to resolve issues of insufficient grain production and consequent economic crises. ${ }^{11}$ In the following centuries, turbulence among the three dynasties (from Spain, Piedmont and Austria) who ruled the island encouraged nobles to go back to the city: in awareness of the collapse of longstanding political balances, aristocratic families returned to the capital to protect their interests. A period of intense building then occurred in Palermo and its environs, as nobles who had previously had nothing more than a pied-àterre in the city built residences. Construction expanded even more after the accession of Charles III in 1735, when the nobility obtained a firmer social and economic position. ${ }^{12}$

10 The citation 'golden century' comes from: Abbate F., Storia dell'arte nell'Italia meridionale: il secolo d'oro (Rome: 2012); the expression was very common among eighteenth-century writers. In 1724, Pietro Vitale connected this city's key period with devotion to the patroness, Saint Rosalia, whose relics were found a century before. Vitale Pietro, Il secolo d'oro aperto a Palermo dalla preziosissima inventione del corpo di S. Rosalia vergine palermitana (Palermo, Antonio Epiro: 1724; reprint, Palermo: 1824) 10.

11 Cancila R., Autorità sovrana e potere feudale nella Sicilia moderna (Palermo: 2013) 47-56; Castiglione P., Settecento siciliano. Città e terre feudali tra malessere e riformismo (Catania: 1982) $30-34$.

12 On the topic see: Piazza S., "Il sistema delle residenze nobiliari", in Atlante tematico del Barocco in Italia, vol. 3: Fagiolo M. (ed.), Il sistema delle residenze nobiliari. Italia Meridionale (Rome: 2010) 304-316. 
Consequently, when the slow decay of Sicilian aristocratic society began at the end of the eighteenth century, the noble families already dwelling in these lavish houses continued to live on in them until the effective financial collapse of their social class. For this reason, and due to the resistance to change shown by the elite in Sicily, extant residences can reveal much about noble lifestyles, notwithstanding the major modifications that these buildings have endured since the beginning of the twentieth century.

Catholic thought saturated every aspect of daily life in Sicily, at all social levels and in all places, inside and outside the home. ${ }^{13}$ The demands of the act of worship itself guaranteed widespread participation, drawing people from all levels of society in shared devotion and, at the same time, respecting hierarchical differences. When Ignazio de Vio narrates how citizens were 'radunati a gran folla ò ne' palaggi, e cafe, ò nella piazza' ('gathered in crowds in palaces, cafés, and piazzas') at the 1693 procession of Saint Rosalia, he seems to divide society into three categories, denoted by these locations. ${ }^{14}$ Aristocrats were more likely to attend the event from their own balconies, from which they could gaze over the people below, rather than joining them in the streets and squares. ${ }^{15}$ However, during the description of the procession of Saints Cosmas and Damian, the Marquise of Villabianca reports that he himself had 'seen civil people of some respectability not disdaining to run behind [the procession] mixing with the plebeians, hoping to obtain from the Saints the end of their pains and because they felt pleasure in running.'16 The episode and the irritated tone of the comment reveal the tension in the nobility's desire to participate in communal devotional life but requirement that they distinguish

13 'After the first victories over the Protestant thought' Sicilian Christian art increasingly underlined the triumphal aspect of Catholicism, dwelling on themes that could have an anti-Protestant meaning, such as the Trinity, the Eucharist, and the Communion of the Saints, since Protestants acknowledged the presence of Christ only inside the liturgical celebration, Stabile F.M., "Sicilia devota e committenza artistica dopo il concilio di Trento", in Malignaggi D. (ed.), Pietro Novelli ed i il suo ambiente, Proceedings of the 1990 Palermo Symposium (Palermo: 1990) 23. It should be said, however, that the Lutheran threat to Sicilian religious life was a distant one; if anything, Islam was a more real danger.

14 De Vio Ignazio, Li giorni d'oro di Palermo nella trionfale solennità di Santa Rosalia, vergine palermitana celebrata l'anno 1693 (Palermo, Pietro Coppula: 1691) 84.

15 Palace facades signalled the celebrations with hanging brocades and velvets, burning torches, canopies and altars set in front of entrances. Isgrò G., Feste barocche a Palermo (Palermo: 1981-86) 44-48.

16 " $\mathrm{H}]$ o veduto io, Villabianca, persone civili e di qualche riguardo non avere ribrezzo a corrervi di appresso meschiati a plebei, sperando nei Santi ottener fine a' loro mali e perché, nel corrervi, vi provavano un gran piacere", Mazzè A. (ed.), Processioni di Palermo sacre e profane (Palermo: 1989) 59. 
themselves in some way. The manner in which religious choices shaped the sense of identity of European aristocratic dynasties and the 'overwhelming power of confessional identities after the Reformation' has been well explored, and the findings hold true in this context. ${ }^{17}$ Individuals felt the need to be connected 'to the city's wider community of Christian devotion. ${ }^{18}$ For aristocrats, the requirement that they act as leaders in the community coincided with being part of the same community, as devotees. The architecture of oratories in rural villas and urban chapels encapsulate this ambivalence between the act of opening outwards and that of withdrawing into one's own environment.

\section{The Architecture of Devotion: Countryside}

Country villas are easier to investigate than urban chapels as numerous examples of the former survive - albeit not always in good condition. Many historians of architecture have shown how villas built in the countryside around Palermo during the period demonstrate strong connections between architecture and setting, residence and garden, home and landscape. ${ }^{19}$ In addition to this, analysis of these villas reveals an interesting, understudied, religious aspect. Palermo's villas are characterised by a geometrical approach to their design. In most cases, private oratories were an integral part of the architectural scheme. Cases in point are three villas in Bagheria, a town in the countryside east of Palermo: Palagonia (built 1658), Valguarnera (1714-1785), and Cattolica $(1706-1736) .{ }^{20}$ The oratories of these residences are, in fact, small churches situated in the outbuildings that surround the house [Fig. 3.1]. In such cases, oratories were rarely just for the use of family members: their quasi-public use was laid out in the document of consecration. These spaces opened themselves up to the community of the surrounding countryside. The oratory was used for regular church services for the families of agricultural workers on the estate,

17 Geevers L. - Marini M. (eds.), Aristocracy, Dynasty and Identity in Early Modern Europe. Rulers, Aristocrats and the Formations of Identities (Aldershot and Burlington: 2015) 17.

18 Morse, The Arts of Domestic Devotion 2.

19 De Simone M., Ville palermitane del 17. e 18. secolo: profilo storico e rilievi (Genova: 1968); Piazza S., Le ville di Palermo. Le dimore extraurbane dei baroni del Regno di Sicilia (14121812) (Rome: 2011).

20 Dates from: Boscarino S., Sicilia barocca. Architettura e città 1610-1760 (Palermo: 1981) $210-212$. 


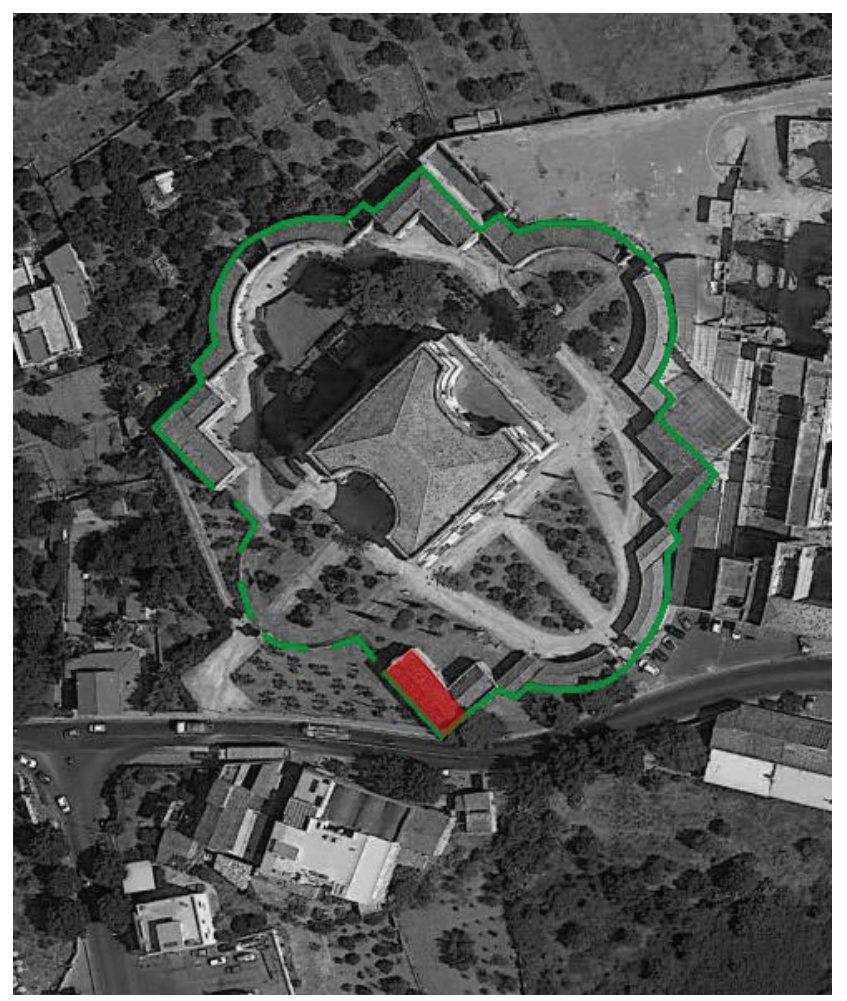

FIGURE 3.1 Villa Cattolica, Bagheria (Palermo), the geometrical disegno of outbuildings is highlighted in green, the oratory is in red MANIPULATION BY THE AUTHOR OF A GOOGLE EARTH IMAGE

especially if there was no other church nearby. Their use in this way explains some features of these rooms: the location of the oratory on the ground floor was obviously a necessity, despite this usually being the level of service rooms such as kitchens and stables. Moreover, the main entrance might be situated on to the inner garden, towards fields, or on to the public road [Fig.3.2]; in the latter two cases the owners would also have had a private entrance, as was the case at the Villa Cattolica [Fig. 3.3]. It is fitting that nowadays, if these oratories are no longer private property, they are often public churches where Sunday services are held for local residents.

This semi-private use seems to have been little influenced either by the dimensions of the oratory or by its proximity to the villa. On the one hand, in the case of very small interior chapels, the congregation could spill over into 


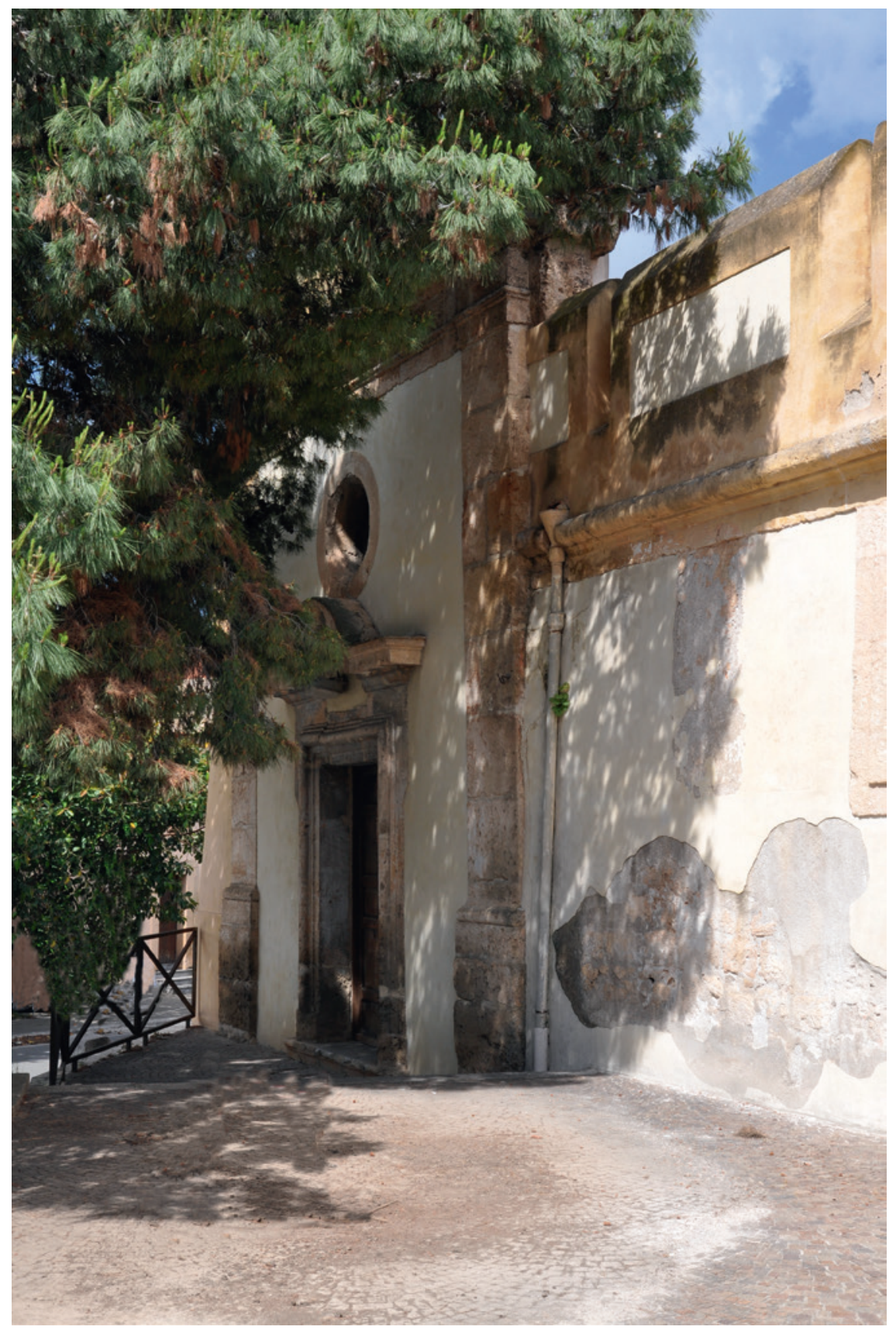

FIGURE 3.2 Oratory of Villa Cattolica, entrance from the street, Bagheria (Palermo) PHOTOGRAPH BY THE AUTHOR 


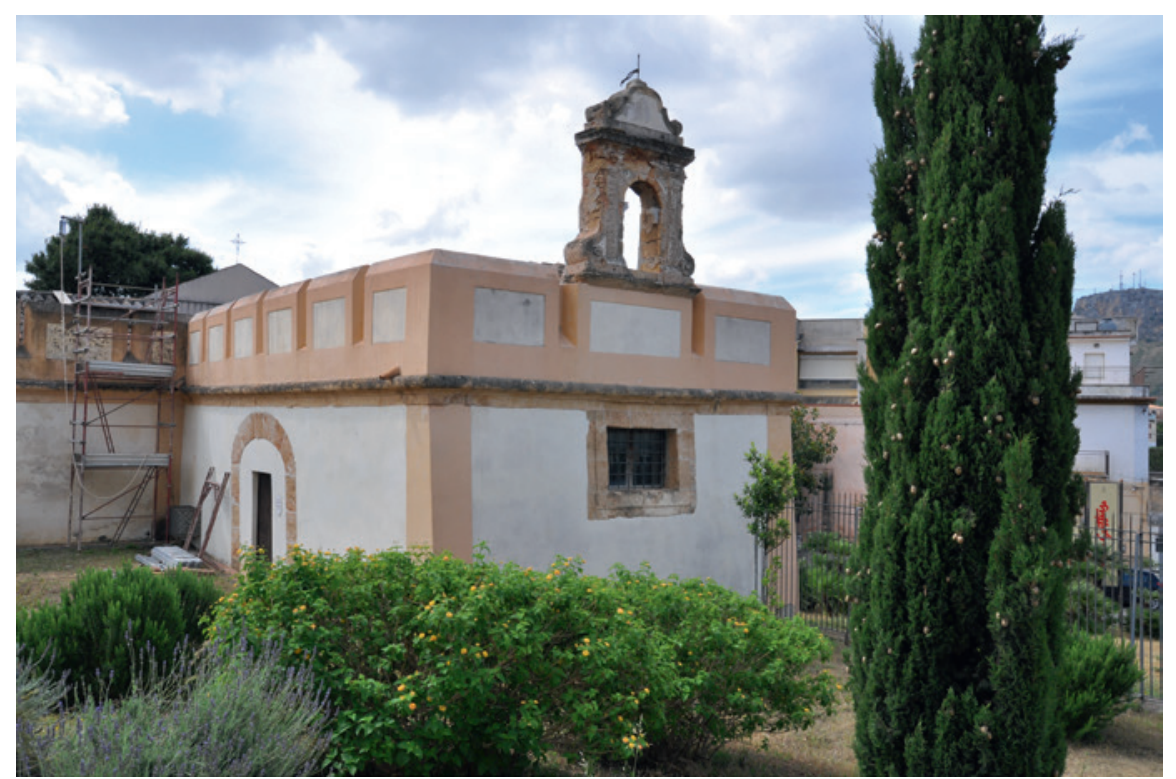

FIGURE 3.3 Oratory of Villa Cattolica, entrance from the inner garden, Bagheria (Palermo) PHOTOGRAPH BY THE AUTHOR

a nearby garden, as is demonstrated by the example of the little chapel inside the Villa La Grua, built in the mid-eighteenth century to the west of Palermo [Fig. 3.4]. This room, which was sadly burgled about ten years ago, is located in a small elliptical space on the ground floor [Fig. 3.5], but potentially its congregation could overflow if necessary out into the external front courtyard (as happened until the recent past, according to the last owner of the villa). ${ }^{21}$ In other words, occasionally a secular space was transformed into a religious one by this practice. On the other hand, there are also examples of oratories close to a dwelling, but neither inside it nor in one of the outbuildings. Such structures were more likely to become independent churches over time. One example is the church built adjacent to the late baroque Villa Terrasi ai colli, an unusually large family oratory that has now been transformed into the parish church of a new quarter of Palermo, San Lorenzo. Similarly, the former chapel of the Villa Filangeri in Santa Flavia is now the main village church. They have lost their private aspect and acquired the function of a public religious edifice.

21 Gustavo De Simone Achates Blanco Wirz, interviewed March 2015. 


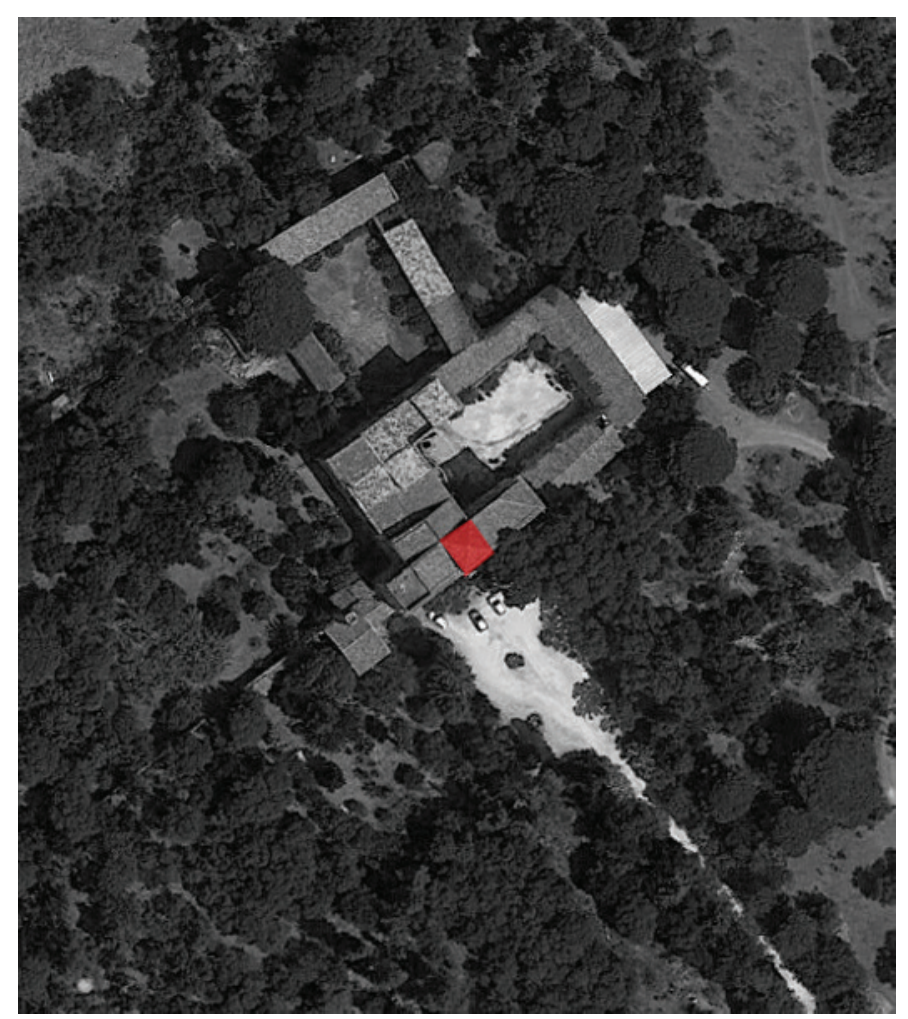

FIGURE 3.4 Villa La Grua, Palermo, the oratory is highlighted in red MANIPULATION BY THE AUTHOR OF A GOOGLE EARTH IMAGE

As these examples show, the oratories of country villas illuminate an interesting aspect of the relationship between noble families - the estate owners - and the people who were economically dependent on their land. Evidently, in this relationship the head of the noble household had a prominent role: providing work, leading the community, and, as we have seen, building the oratory. A significant role was also played by female members of the nobility. An example is the case of the Branciforti di Butera family in Bagheria. In this small town, Prince Giuseppe lived in his huge palazzo in self-imposed exile from Palermo. The tree-lined avenue that was the primary path to the villa is now the main road of the town, but the relationship between the Palazzo Butera and the village is more profound. According to Francesco Michele Stabile, in 1702 Donna Agata, sister of the Prince and heir of the propriety at his death, gave her peasants a small chapel dedicated to the Madonna of the Rosary on land not far away 


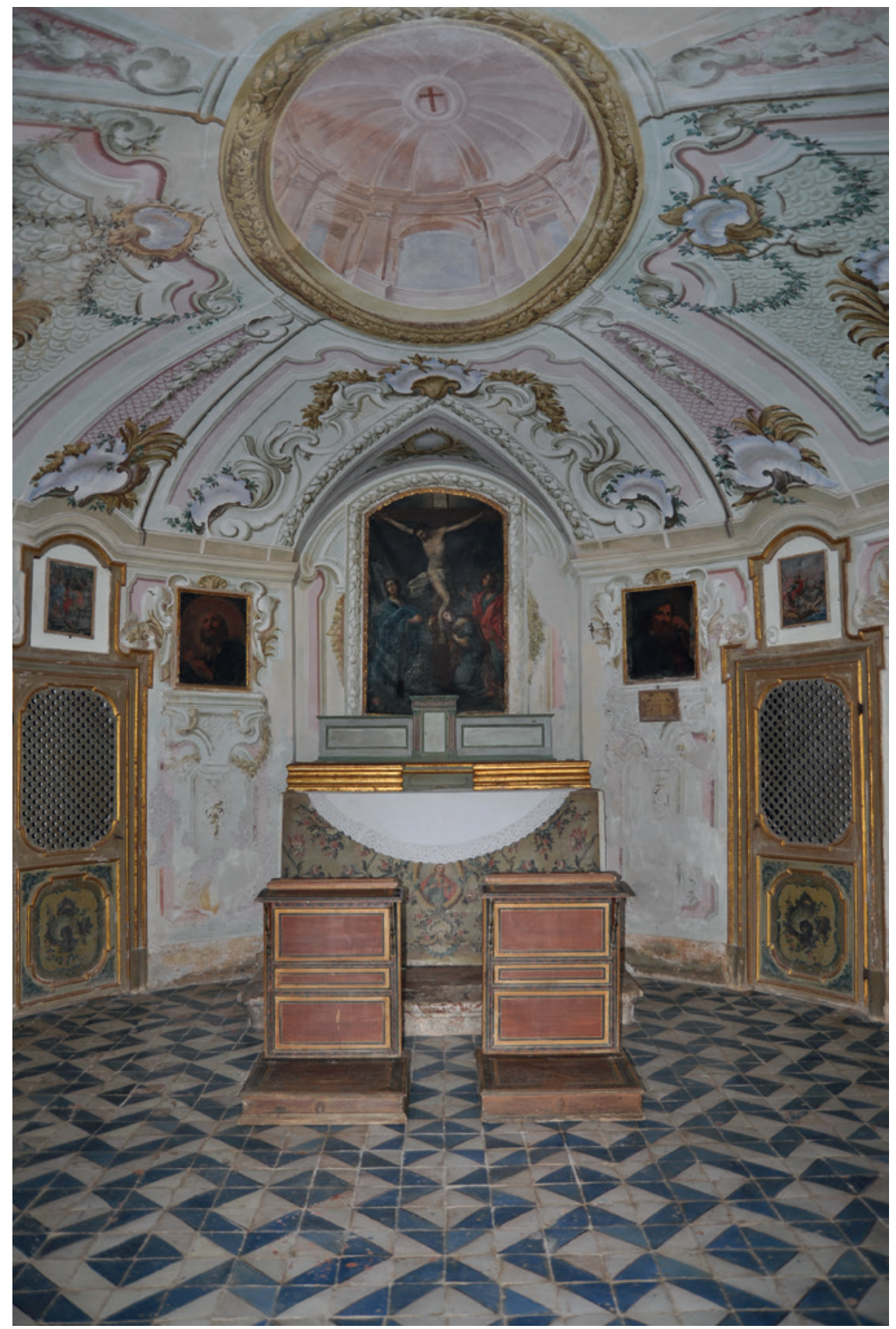

FIGURE 3.5 Chapel on the ground floor of Villa La Grua

PHOTOGRAPH BY THE AUTHOR, BY KIND PERMISSION OF GUSTAVO WIRZ 
from her villa, to bury their dead. ${ }^{22}$ Thereafter, in 1707 she obtained from the Archbishop permission to convert the oratory that was within the area of her own house into a parish church with a baptismal font available to peasants for the sacraments of baptism. ${ }^{23}$ In return, she promised to manage the daily maintenance of the church and to provide a stipend for its priest. We do not have enough evidence to judge if a woman such as Agata was motivated merely by a sense of a duty to the spiritual welfare of the community, or by a desire to control everyday aspects of people's lives, or maybe by a combination of both. These cases, however, should be framed inside the broader context of interactions between elites and peasants that took place within countryside villages, since at the beginning of the seventeenth century, noble families were allowed to buy royal privileges, such as the 'licentia populandi' and the 'merum et mixtum imperium', in order to incentivise the repopulation of the countryside. ${ }^{24}$ This community aspect, however, is almost absent in the city, where chapels set in urban palaces operated quite differently.

\section{The Architecture of Devotion: City}

Unfortunately, examples of urban chapels are fewer in number and less well preserved than oratories of villas, but we do have an important source from the period who debated the question of such chapels, namely the architect and priest Giovanni Biagio Amico (1684-1754). As already noted, the aristocratic and conservative Marquis of Villabianca had complained that the older and grander style of residence was gradually falling out of fashion amongst Palermo's noble families and that as a result the size of chapels was reducing over time. By contrast, in the second volume of his L'architetto pratico (The

22 Stabile F.M., "La Parrocchia della Bagaria. Dallo spazio del Principe al patronato municipale (1708-1858)", in Scaduto R. - Stabile F.M. (eds.), Le acque del Salvatore nel villaggio di delizie della Bagaria, Proceedings of the conference held in Bagheria on 13rd February 2009 (Palermo: 2010) 21.

23 Stabile, "La parrocchia della Bagaria" 22 . The Butera family oratory was the only church in Bagheria until the building of the current main church (1769-1771).

24 These privileges allowed them to found villages and to administer justice for the villagers; see Cancila R., Autorità sovrana e potere feudale nella Sicilia moderna (Palermo: 2013) 15-64. As Domenico Ligresti argues, controlling a fief and founding a new village could give families prestige in many ways: giving access to the Braccio militare of the Parliament, enhancing the political role of the family, providing more prestigious aristocratic titles, increasing incomes and unlimited power over the population. Ligresti D., "Per un'interpretazione del Seicento siciliano", Cheiron 17-18 (1992) 93. 
Practical Architect) of $175^{\circ}$ Giovanni Biagio Amico explicitly recommends that such smaller spaces should be incorporated into dwellings. He stated that the chapel should be located among the backrooms of the 'piano nobile', the primary floor of the residence, close to the 'alcova' in order to allow attendance at mass even in case of sickness. ${ }^{25}$

On the first floor, Amico listed as necessary the following rooms: 'the main entrance, anterooms, rooms for receiving and sleeping, the gallery, the library, the chapel, lodges, backrooms, service area, fireplaces, secret passages, pantry, and other rooms suitable for the Mistress and the Master.'26 At this point, Amico lingers in the passage from the anterooms to the backrooms, through the bedroom, introducing a series of intermediate rooms. ${ }^{27} \mathrm{He}$ does not use the terms private or public. As Giulia Calvi writes, 'from the sixteenth to the eighteenth century, no one would have placed family and familial relationships, religious profession or devotion in the private sphere or in the realm of individual choice. ${ }^{28}$ Yet, from the sequence of rooms provided by Amico a slight distinction emerges between the anterooms and the backrooms, between what was visible to the judging eyes of a visitor and what was not. Along with the stairs, loggia, and entrance, which should provide the palace with 'magnificenza' and 'grandezza', the anterooms were assigned with the explicit function of 'making the palace magnificent'. ${ }^{29}$ By contrast, Amico

25 'La cappella suol situarsi anche presso alla camera di dormire, e sarà ben fatto il disporla in modo, che anche dal letto possa ascoltarsi la messa in caso di malattia', Amico Giovanni Biagio, L'architetto prattico in cui con facilità si danno le regole per apprendere l'architettura civile (Palermo. Nella Stamperia di Angelo Felicella: 1750; reprint, Palermo: 1997) 67-69. The 'retro-camere', or backrooms, were rooms behind the bedroom, usually conceived of as private spaces. The 'alcova' was a tripartite space that housed, under a central wooden vault, the bed and the bedside tables and, laterally, two small rooms or passages, possibly divided per sex. In some documents, the term can be found as a synonym for bedroom, but in those days the alcove was more an optional addition to the main bedroom.

26 '[L]a Sala, le Anticamere, le Camere d'udienza, e di dormire, la Galleria, la Libraria, la Cappella, le Logge, le Retrocamere, i Gabinetti, i camini, i Passetti segreti, la Credenza, e tant'altre officine civili per comodo della Dama o del Padrone.' Amico, L'architetto prattico 64. Amico states 'now, the apartments according to Sicilian custom are arranged, as follows' (ora gli appartamenti giusta il costume di Sicilia si dipongono così). Amico, L'architetto pratico 66. The phrase reveals that, although intending to list general prescriptions, the author gives us a glimpse of the contemporary customs of his land and it is likely that the author benefitted from direct knowledge of most of the residences already built in Palermo.

27 Amico, L'architetto prattico 67.

28 Calvi G. (ed.), Barocco al femminile (Rome - Bari: 1992) XI.

29 "[R]endere magnifico il palazzo." For this reason, Amico suggests that their doors must be placed in sequence (enfilade). Amico, L'architetto pratico 66. 
associates the backrooms with a function more related to what he considers to be women's activities. These activities, together with the reduced size of the backrooms, hint at a more intimate atmosphere. The bedroom and its 'alcova' were deemed, by Amico, as a sort of boundary between these two areas. This could be constituted by a single room, or by two rooms, the 'camera di parata' and the real bedroom behind it. One could also add a further passage through the narrow 'gabinetti' flanking the 'alcova', pushing the backrooms back even further. This complexity blurs the boundary between areas. At any rate, this space was never thought to be off-limits, as family members, servants, and the closest friends continually entered it. ${ }^{30}$

The sequence of rooms Amico describes can be compared to that that Patricia Waddy outlines for the apartment in seventeenth-century Rome [Fig. 3.6]. ${ }^{31}$ Apart from some additional spaces, the suggested proportions, and the different names of the rooms, the two are very similar. Yet the position of the chapel is remarkably different [Fig. 3.7]. Amico places the domestic chapel inside the bedroom area and not outside it, as in the Roman model. This creates a sharp contrast with the greater visibility that the chapel had in the Roman palace, where it opened onto one of the anterooms. This probably results from the fact that what Waddy reports is 'a set of rooms for the use of a single important resident, and the model resident was a cardinal. ${ }^{32}$ Therefore, even if the chapel 'had a window to an inner room of the apartment, from which the cardinal could hear mass privately' daily celebrations must have been occasions for fairly large gatherings in one anteroom. ${ }^{33}$ The visibility of the chapel, in this case, could have underlined the fact that the palace's resident was a member of the Church. Contrastingly, Amico suggests a more intimate context for the chapel, which would have been neither physically accessible nor visible to the majority of visitors [Fig. 3.8].

The location of the chapel on the first floor was undoubtedly the most frequent (even if this was not universally the case). ${ }^{34}$ Its presence on the same floor as the family activities entailed its inclusion in daily life. ${ }^{35}$ It is not un-

30 Amico himself reports the presence of servants who could be asked to sleep in the backrooms, or to cook there. He also mentions the presence of nannies, which implies the presence of children, see Amico, L'architetto pratico 67.

31 Waddy P., Seventeenth-century Roman Palaces: Use and the Art of the Plan (New York Cambridge: 1990) 3. The scheme is on page 5 .

32 Waddy, Seventeenth-century Roman Palaces 3.

33 Ibid., 7 .

34 For instance, the palace of the Prince of Valdina used as a chapel a small medieval church that had ended up in the courtyard of his palace; see Mazzè, I Palazzi regi di Palermo 98.

35 To understand the importance of being set on the piano nobile level, an example is that of the chapel of the Holy Shroud in Turin. This room, even if it was part of the city 


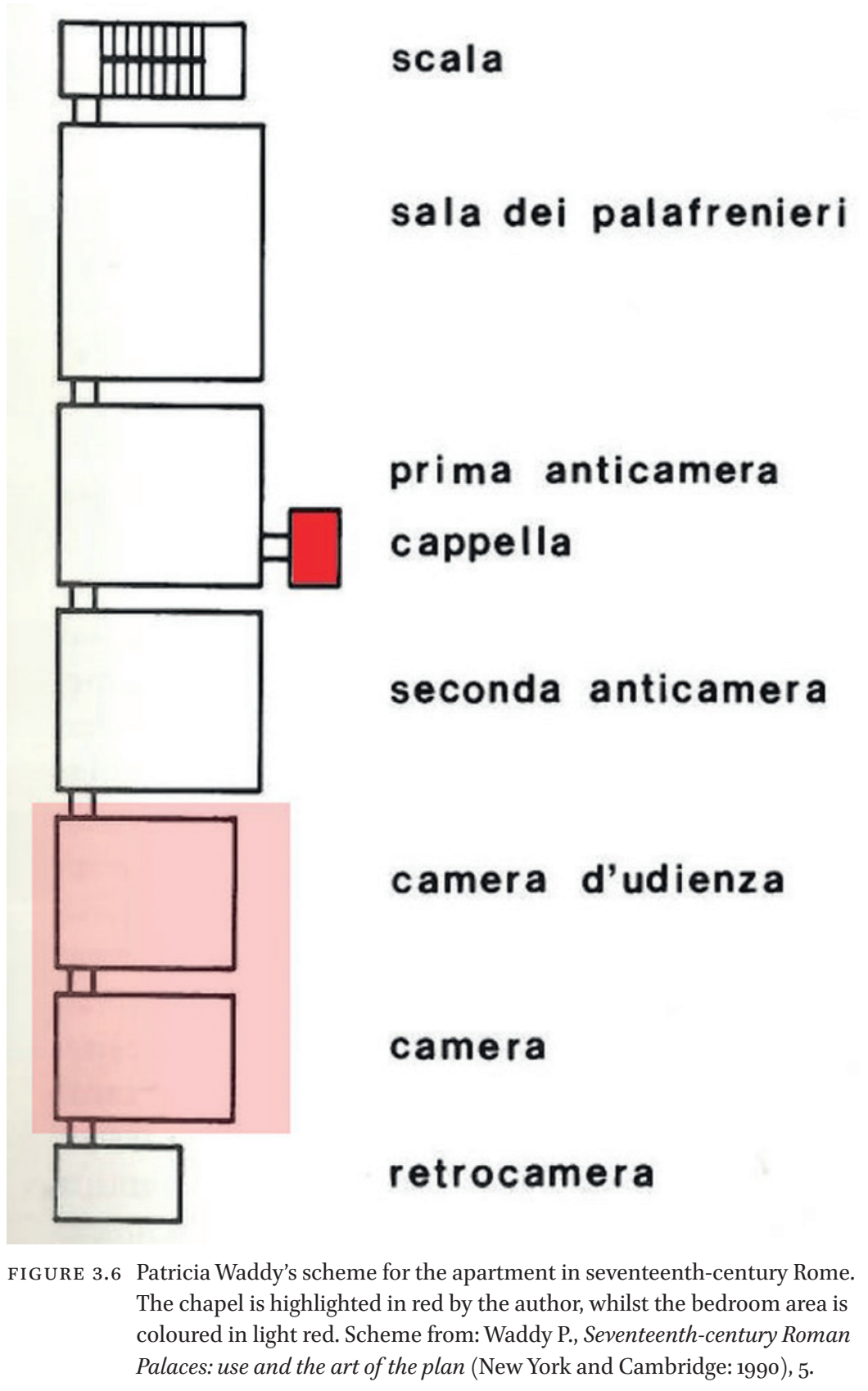




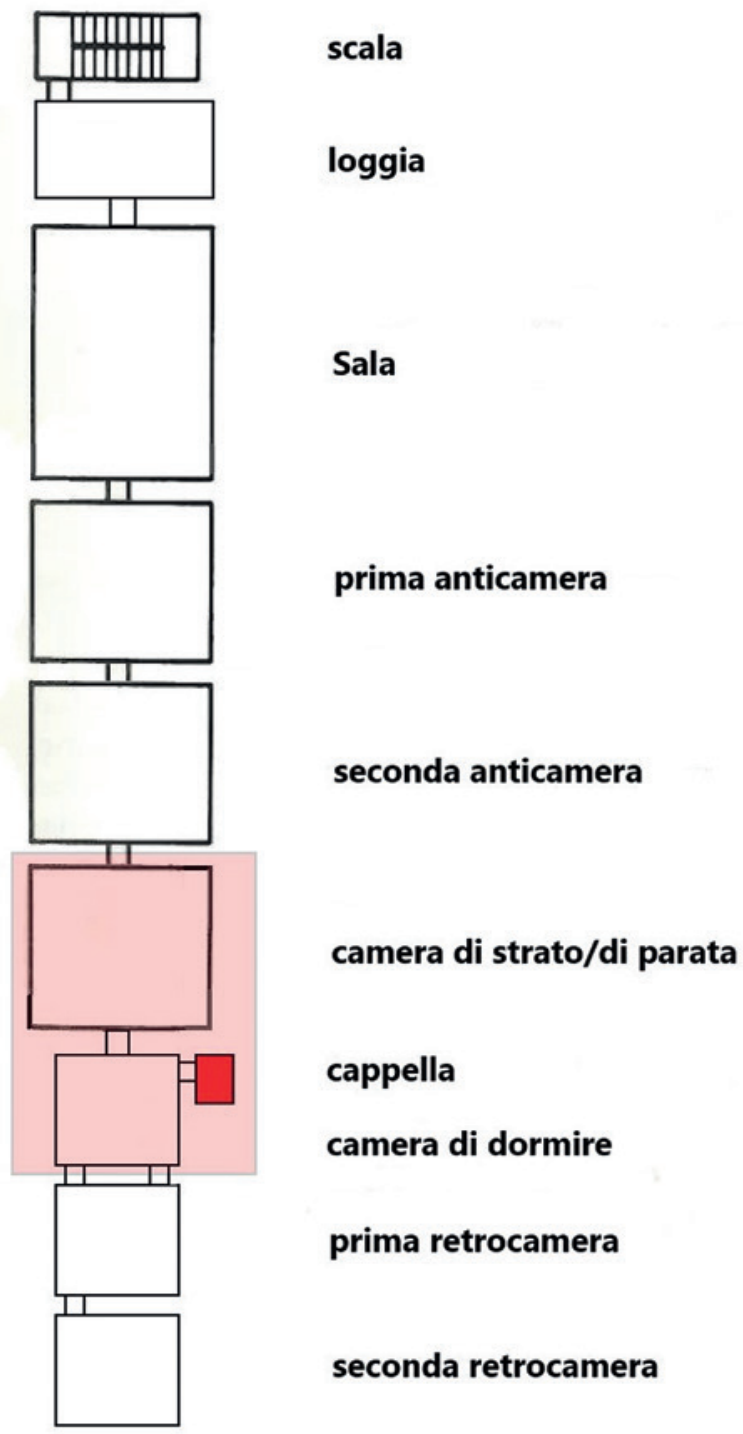

FIGURE 3.7 Scheme of the apartment in late seventeenth- and early-eighteenth-century Palermo by the author, based on the description by G.B. Amico. The chapel is highlighted in red, whilst the bedroom area is coloured in light red. 


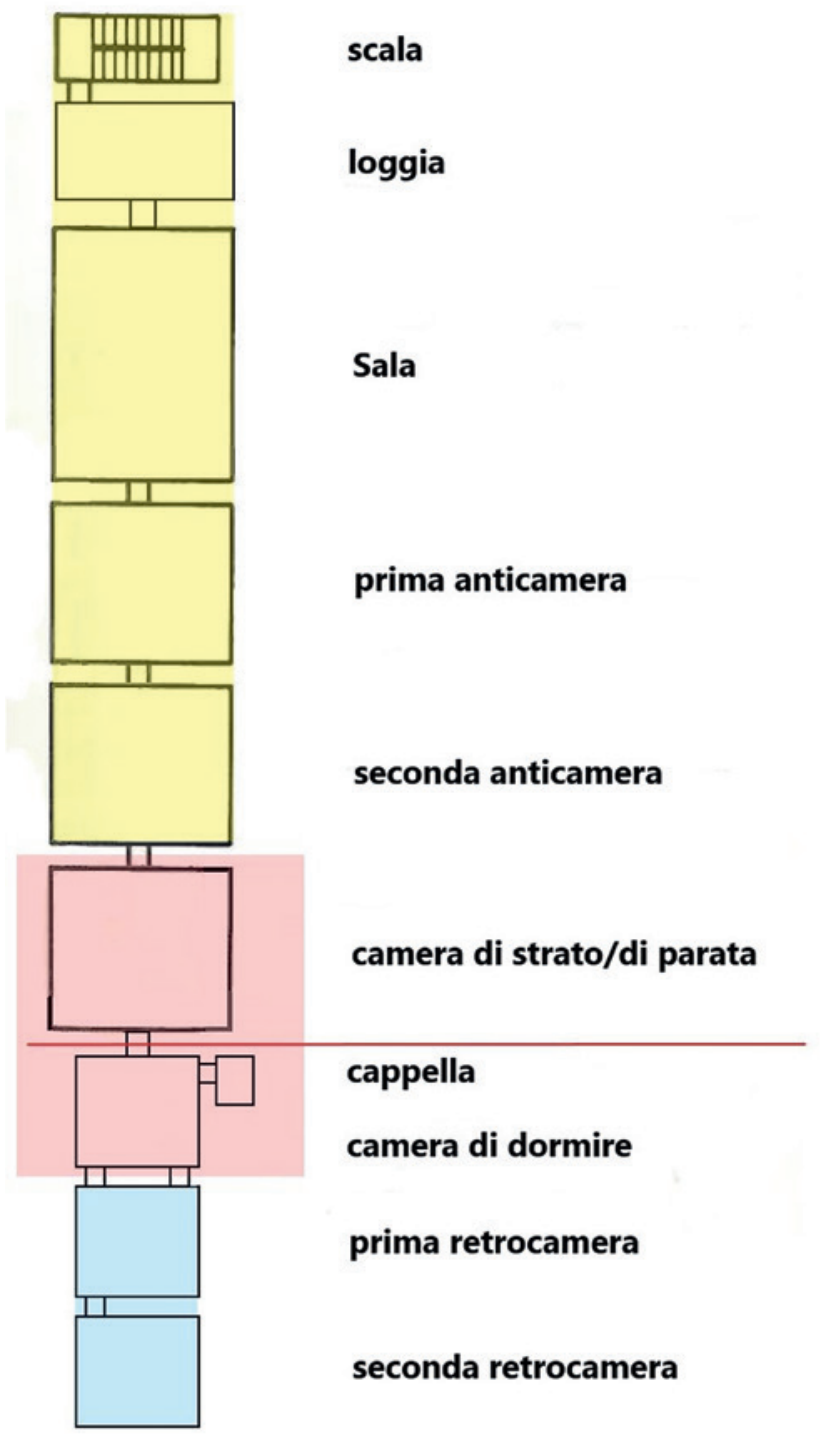

FIGURE 3.8 Scheme based on the description by G.B. Amico. The rooms shaded yellow represent the spaces that were most public, those in blue the most private, and those in red the more liminal. The red line indicates the limit to an outsider's gaze. 
usual to find in contemporary documents more than one chapel listed on the same floor, since the piano nobile was often divided into two or three sets of apartments. ${ }^{36}$ At the time of his death in 1697, Don Francesco Alliata, prince of Villafranca, had a chapel in his bedroom, on the first floor of his Palazzo in piazza Bologni (most probably only an altar in a niche or a piece of furniture covered by curtains). ${ }^{37}$ His widow Margherita, building her own apartment on the same floor in 1698-1700, planned to have two new chapels close to her own bedroom, one large and the other small: 'la cappelluzza.' 38

The fact that the bedroom was the most usual place for worship is not a surprise. ${ }^{39}$ The issue is addressed in a book written by Calisto di Missanello, printed in 1647, which was aimed at members of the numerous and widespread confraternities dedicated to the Madonna of the Rosary. ${ }^{40}$ The book's subtitle, ' $[\mathrm{m}]$ any and diverse ways to meditate and recite the most holy Rosary in Chori or individually', reveals that it was intended for common people. ${ }^{41}$ The fourth chapter reports that every good Christian must pray and meditate three times a day: early in the morning, soon after lunchtime, and in the evening. ${ }^{42}$ Whilst morning prayer can take place in church, the other two are described as domestic activities, one at the table and the other 'with all your family in front of the oratory'.43 Furthermore, Calisto refers several times to the evening prayer taking place just before going to sleep, thus linking the chapel (or

Cathedral, became for everybody "the royal chapel" since it was positioned by Guarino Guarini on the first-floor level of the Savoy Palace and connected to its interiors. Scott J.B., "Seeing the Shroud: Guarini's Reliquary Chapel in Turin and the Ostension of a Dynastic Relic", The Art Bulletin 77, 4 (1995) 6o9-637.

36 In 1777, the Palazzo Comitini contained at least two 'camerini priega Dio' (literally, small rooms to pray to God) provided with kneeling stools. Zalapì A., "La lunga genesi di Palazzo Comitini”, in Zalapì A. - Rotolo M. (eds.), Palazzo Comitini (Palermo: 2011) 267-270.

37 ASP, Alliata vol. 2831, fol. 244v.

38 Asp, Notai defunti, Not. Gandolfo Cosimo, vols. 4985-4986.

39 Corry - Howard - Laven, Madonnas \& Miracles 10.

40 Calisto di Missanello, Regola e Costituzioni, Essercitij Spirituali, e Cerimonie da osservarsi nelle Congregazioni, e nelle Compagnie del Santissimo Rosario (Napoli, Francesco Savio Stampatore della Corte Arcivescovale: 1647). There is no evidence about the origin of the sample in Palermo, but hand-writing on the first page seems to recite 'Lettoris fr. Antonini Abbati Ordinis Predicatore' as if it was owned by a preacher of Saint Antonio Abate's order.

41 'Molte e diverse maniere di meditare, e recitare il Santissimo Rosario, tanto à Chori, quanto in privato.' The wording à Chori refers to the habit of reciting the Rosary, both in church and at home, by alternating between a single voice and a group of voices. On the other hand, in privato or privatamente refers to the way the confriars pray alone, for example during the daily Spiritual Exercises mentioned further on in the book.

42 di Missanello, Regola e Costituzioni 195.

43 '[C]on tutta la tua famiglia avanti l'Oratorio', ibid. 260. 


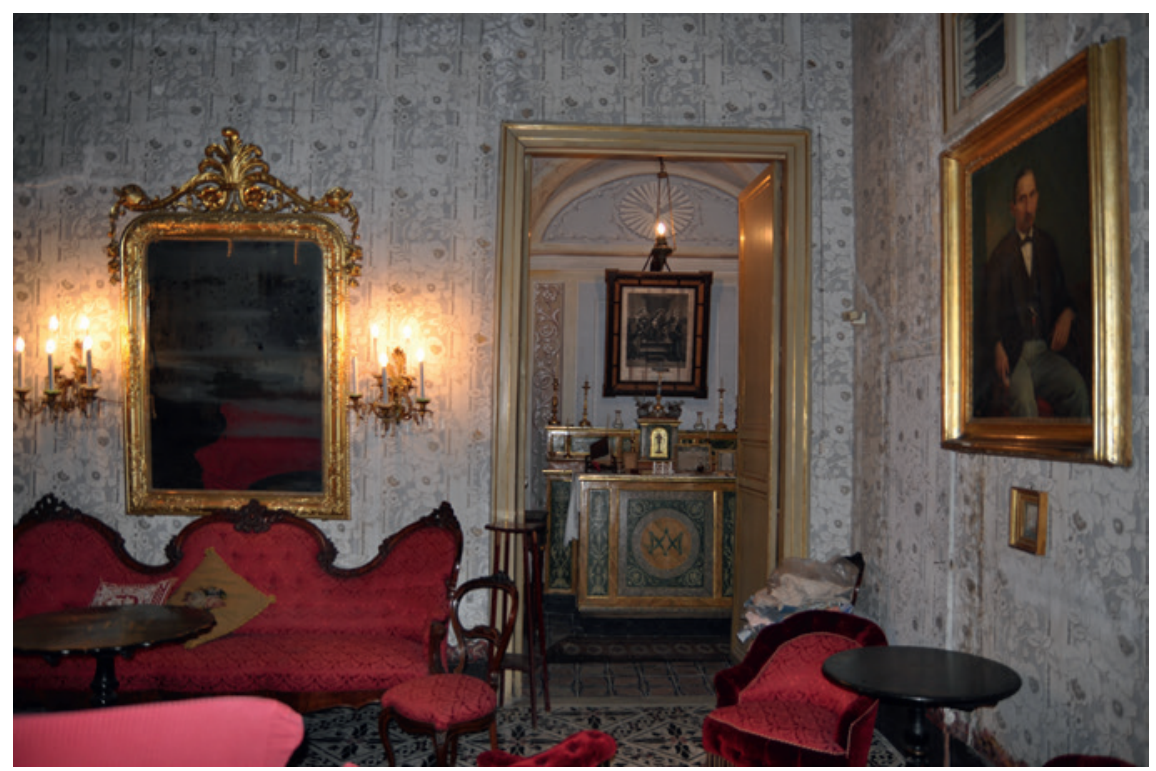

FIGURE 3.9 Chapel and salon on the first floor of Palazzo Raffadali PHOTOGRAPH BY THE AUTHOR, BY KIND PERMISSION OF MARIA TERESA PANZERA

the oratorio, as he calls it) to the bedroom. The author comments on it being commonplace for people who had gone to sleep in the evening to be found dead the following day. ${ }^{44}$ In order to mitigate this risk, Calisto writes of the necessity of reciting monthly in the evening prayers what he calls 'last wishes of the soul' (ultime volontà dell'anima) 'in the form of a testament' (in forma di testamento). ${ }^{45}$ Calisto advises the worshiper to carry out an examination of his or her own sins, to search for God's forgiveness, to promise to make amends the day after, and to pray to the Blessed Mary. ${ }^{46}$ The fear of death during sleep prompted devotees to search for divine protection to ensure their survival whilst also preparing for the worst. The proximity of the chapel to the bedroom was frequent but not strictly observed. The well-preserved chapel in Palazzo Raffadali (ca. 1650) [Fig. 3.9] and the no-longer extant one in

44 '[P]uò essere, che quella notte sia l'ultima, che vive e molti sono colcati sani e salvi la sera, che poi sono stati ritrovuati morti la mattina' (It may happen that that night is the last that [one] lives, as many went to bed safe and sound in the evening and have been found dead the [next] morning)', ibid. 261.

45 Ibid., 106.

46 Ibid., 26o. 


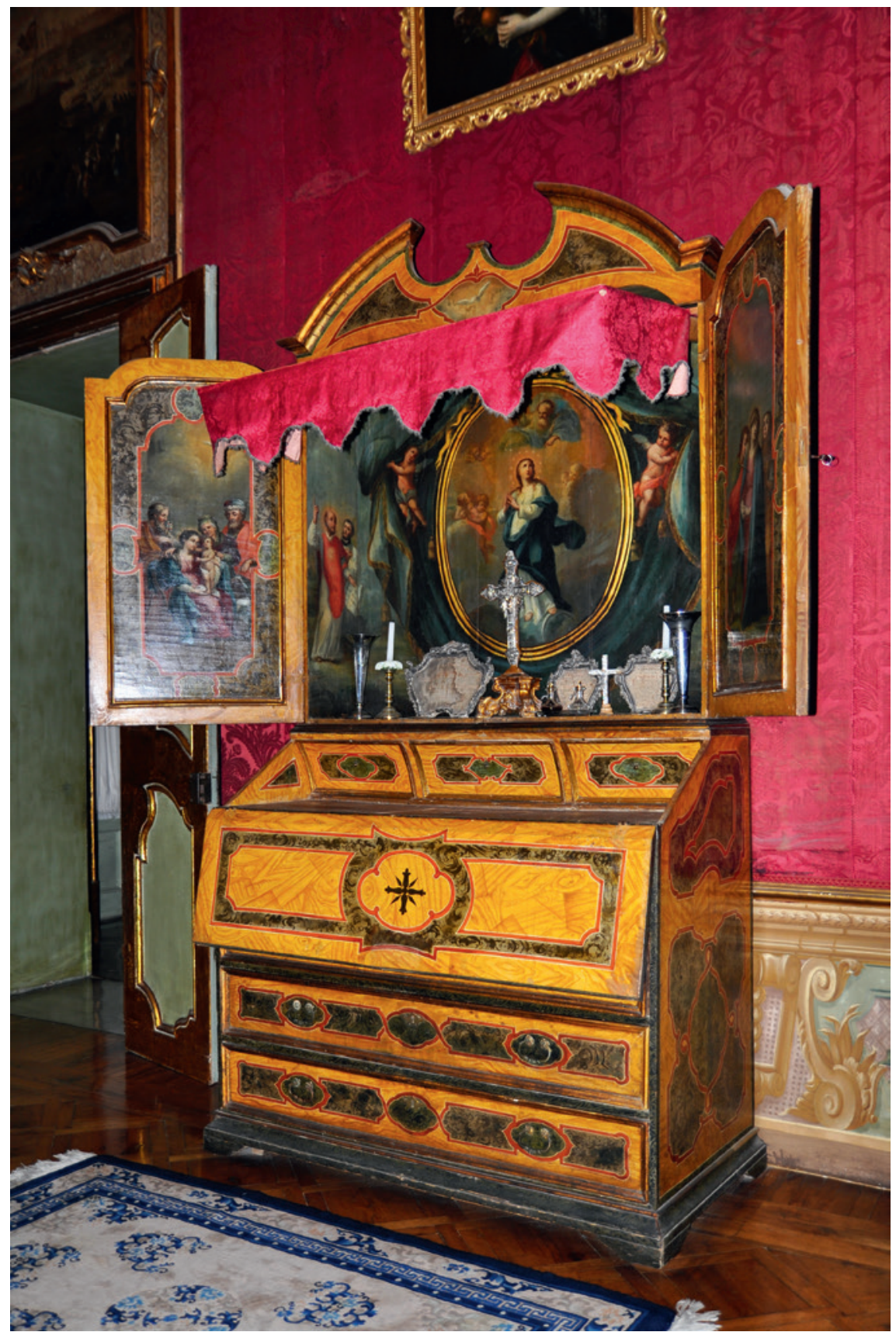

FIGURE 3.10 Altar closet in Palazzo Termine

PHOTOGRAPH BY THE AUTHOR, BY KIND PERMISSION OF SIGNORETTA ALLIATA 
Palazzo Termine (1747) were each separated from the bedroom by a 'camerone' (large hall). ${ }^{47}$

A final point worth mentioning is that if family documents recorded a salary given to a priest who celebrated masses in the house, it could also be that the services were not held in one specific place. It was possible for an altar to have been placed inside a niche of a salon or moved from one room to another like a piece of furniture. There is an example of the former case in the Villa Palagonia where, in addition to the semi-public oratory outside the house, there is a small hall with an altar in a niche which could easily return to use as a public room when the closet shutters were closed. An example of a large altar closet from the eighteenth century can still be found in a salon of the Palazzo Termine [Fig. 3.10], preserved in good condition. Inset into the flat surface of this wooden altar there is a consecrated stone and, at the feet of the closet, a removable platform that makes it possible to conduct the service from a step above the congregation. Cavallo-Evangelisti observed that '[i]gnored for a good part of the day or hidden in a cupboard or behind a curtain, the domestic altars could become the focus of devotion at certain moments, transforming the home into a church with the help of a variety of objects, words and gestures (such as genuflection or the singing of psalms) which were usually associated with consecrated spaces. ${ }^{48}$ This prompts a question about how the chapels were used. Were they just places for family prayers, such as the Rosary suggested by Calisto, or also for celebration of mass in festive days?

The Situation after Trent

In general terms, the Catholic Reformation reaffirmed the importance of the real presence of Jesus Christ in the Eucharist and enhanced adoration of the Eucharist outside the mass as well as within it. ${ }^{49}$ As far as Trent had allowed the preservation of the Eucharist in the tabernacle, it facilitated various forms

47 Pecoraro Marafon M. - Palazzotto P. - Vesco M., Palazzo Alliata di Pietratagliata tra tardogotico e neostili. Archivi, cantieri, protagonisti a Palermo (Palermo: 2013) 52; Cedrini R. - Tortorici Montaperto G., Repertorio delle dimore nobili e notabili nella Sicilia del XVIII secolo. Intra Moenia. (Palermo: 2008) 272.

48 Introduction in Cavallo S. - Evangelisti S. (eds.), Domestic Institutional Interiors in Early Modern Europe (Aldershot and Burlington VT: 2009) 7.

49 Decretum de ss. Eucharistiae Sacramento. Can. 7, in Denzinger H. - Hünermann P., Enchiridion symbolorum, definitionum et declarationum de rebus fidei et morum (Wirceburgi: 1854) 195 . 
of Eucharistic adoration, such as the Forty Hours' devotion. ${ }^{50}$ At the same time, however, the Council of Trent tried to prevent unsupervised celebrations of the Eucharist. This included subjecting domestic oratories to a strict procedure for obtaining a licence. Yet my on-going research is shedding light on the high number of domestic chapels in Palermo in the post-Tridentine period, both in villas and in urban palaces. Unfortunately, since large intervals exist in the diocesan archive for the licence release reports, it is not easy to establish how many of these places had a regular licence and could - licitly - be used for the celebration of mass. ${ }^{51}$ But it is clear that a gap existed between prescriptions and practices, and that the implementation of the new rules was delayed by opposition to, negotiation with, and circumvention of the imposed control.

In Palermo, interference from Rome was resisted both by the laity and the clergy, who were afraid of losing their privileges. Palermo's post-tridentine synods, held in 1555, 1560, and 1564, were not welcomed at all, as they promoted reforms that gave greater power to parish churches, upsetting the pre-Tridentine balance of familial relationships, social norms and shared cultural values that regulated the complex spiritual panorama of Palermo. ${ }^{52}$ Confraternities, congregations, and companies wanted to maintain their influence on daily religious practices, and the Cathedral Chapter preferred to give only part of the city governance to parish churches, in order to preserve its control over the administration of the Sacraments and religious processions. ${ }^{53}$ When the 1586 synod, guided by archbishop Cesare Marullo, finally succeeded in executing the reforms of Trent, on 23rd June of the same year several clergymen turned to the Holy Congregation of the Council to protest against Marullo and report that his reforms were 'occasions of infinite infelicity'. ${ }^{4}$ This search for autonomy in the management of the sacred primarily involved aristocrats, who dominated the city's main religious institutions and associations. ${ }^{55}$

Given this context, it seems reasonable to assume that the new procedure for authorising the celebration of mass inside domestic chapels must have

$50 \quad$ Scordato C., Il Settenario sacramentale (Trapani: 2007) vol. 1, 189-190.

$5^{1} \quad$ Reports from 1663 and 1667 and from 1672 to 1692 are lost.

52 Rurale F., "Stato e chiesa nell'Italia spagnola: un dibattito aperto", Cheiron 9 (1992): Signorotto G. (ed.), L'Italia degli Austrias. Monarchia Cattolica e domini italiani nei secoli XVI e XVII 357-380; Scalisi L., Il controllo del sacro. Poteri ed istituzioni concorrenti nella Palermo del Cinque e Seicento (Roma: 2004) 9.

53 Scalisi, Il controllo del sacro 24.

54 Savagnone G., Concili e sinodi di Sicilia (Palermo: 1910) 142. Eventually, the reasons for the protest were refused.

55 Königsberger H., The Government of Sicily Under Philip II of Spain. A Study in the Practice of Empire (London: 1951) 105-116; Ligresti, "Per un'interpretazione del Seicento siciliano" $86-89$. 
been resisted by the ruling class. This can be proved by the fact that not everybody in Palermo hurried to settle the matter, and the application of the whole procedure was remarkably delayed. Pope Paolo v wrote to Palermo's Archbishop Auria in July 1615:

Most illustrious and reverend lord. The illustrious fathers, interpreters of the Council of Trent, have already invalidated previously obtained licences to celebrate the Eucharist in private oratories, at the hand of local ordinary priests without the Pope's approval; however, so that distinguished people, eminent ministers of public affairs, sick or old aristocrats, and those who are prevented from accessing churches for various reasons may not be deprived of that spiritual consolation, His Holiness, due to the paternal charity with which he embraces everybody, and due to his pastoral concern, especially considering people's needs, grants a two-month extension to the above-mentioned people for the licences obtained before the letter of the Congregation was written on this subject and so that everything written is observed precisely. ${ }^{56}$

The Pope suggested a temporary remedy for 'distinguished people' who still, at the dawn of the seventeenth century, had a licence without papal approval for their private oratory. The deferment may result from a negotiation between clergy and aristocratic families, but it demonstrates, nonetheless, that the devotional practice was not yet completely aligned with the Tridentine prescriptions, since there were domestic chapels in Palermo that lacked proper authorisation but were still in use.

Although the licences issued in the eighteenth century are better documented, at the moment we do not have sufficient evidence to assess with certainty whether compliance with the prescriptions laid down by the Church

${ }_{5} 6$ 'Illustrissime ac Reveredissime Domine. Quas licentias in privatiis Oratoriis Sacrum faciendi hactenus ab Ordinariis Locorum quisque affectus est, etsi Sanctissimo Domine Nostro annuente non ita pridem nullas, atque inanes decreverint Illustrissimi Patres Tridentinii Concilii Interpretes; cum tamen Personas Titulo insignes, Rerumque publicarum primarios Ministros, Nobiles itidem cum aegrotant, aut senio confecti sunt, qui ad Ecclesias accedere multifariam praependiuntur, non deceat hac spirituali consolatione destituit, Sanctitas Sua pro paterna, qua omnes amplectitur caritate, ac pastorali sollititudine, quorum maxime congruit pietatem quoque, necessitatemque spectans, Amplitud. V. Illustriss. potestatem facit, duraturam tamen ad duos proximos menses dumtaxat, has licentiasin ista Civitate, et Diocesi suprascriptis Personis concedendi, quae aesdem ab Amplit. V. Illustriss. ante Litteras Congregationis hac de re editas, atque ita ut infrascripta omnia exacte observentur', Gattico Joannes Baptista, De Oratoriis domesticis et de usu altaris portatilis (Roma: Typographia Generosi Salomoni, 1746) 141-142. 
was then achieved. The fact that licences were given ad personam and could not be transmitted to heirs means that their number in a specific time cannot be used to estimate the number of chapels built in the same time. For instance, in 1724 the Prince of Scordia Ercole Branciforti and Naselli obtained a licence for the domestic chapel already extant in the palace and most probably built by his grandparents at the end of the previous century. ${ }^{57}$ In addition, what is emerging is that the presence of an authorised chapel in a building did not preclude the need for others. Ignazio and Giovanna Lanza Duke and Duchess of Camastra had already obtained a licence for their chapel in their Palazzo in Piazza del Cancelliere (now lost), in $1714 .^{58}$ Nonetheless, in 1738 the Duchess ordered a second one to be included in the extensive renovation of the palace. ${ }^{59}$ The relationship of family members with these devotional spaces should probably be sought not so much in their suitability for celebration of mass, rather in that spiritual support to the person that could be realized with the recitation of the Rosary or even solitary prayers.

The Diocesan archive records that the number of approvals for new private oratories issued by the Church only started slowing down in the 1920 s when this practice was strongly discouraged by canon law in favour of religious life better integrated with the surrounding parish community. ${ }^{60}$ This was reaffirmed by the Sicilian Bishops' Conference in 1992, and in 1994 by the Archbishop of Palermo personally: he outright prohibited the celebration of weddings 'in private chapels and definitely not inside both private houses and villas, even if they are provided with a chapel'.61 Of course, the necessity of reiterating the prohibition indicates how frequent religious ceremonies in homes remained and how difficult it has been to eradicate these customs, even at the turn of the twenty-first century.

In conclusion, although research is on-going, through consideration of examples located in Palermo and its closest surroundings this paper has tried to establish some fundamental points. Even if everywhere the categories of private and public, and secular and religious, tended to blur and overlap, it can be asserted that oratories in villas were more open to the neighbourhood

57 ADP, n. $1022(1714 / 1724)$, fols. 133r-134r.

58 Ibid., fols. 131v-132r.

59 Asp, Trabia, Serie A vol. 403, fol. $277 \mathrm{v}$.

6o Since 1917, canon law has stated that 'Actiones liturgicae non sunt actiones privatae, sed celebrationes Ecclesiae ipsius, quae est "unitatis sacramentum", 'liturgical actions are not private actions but celebrations of the Church itself which is "the sacrament of unity"' (CIC, can. 837 §1).

61 Pappalardo S., "Disposizione in ordine ai matrimoni celebrati in ville o case private", Rivista della Chiesa Palermitana 17 (1994) 297. 
and more closely intertwined with the aristocratic role of guiding the spiritual lives of rural people, whereas urban chapels testify to a more intimate concept of domestic devotion that often placed the chapel close to the bedroom. Although at the moment it is not entirely clear to what extent these spaces were in compliance with the post-Tridentine rules about the celebration of mass, it is evident that the regulations did not negatively affect the building of new oratories and chapels, and their inclusion in aristocratic familial dwellings is an exceptionally long-lasting phenomenon. The wide variety of examples points to the need for more detailed case-by-case study. Meanwhile, however, material documentation is vanishing, as many palaces and villas have been gradually abandoned, stripped of furniture, adapted for new functions or divided into flats, and the locations of past sacred spaces are changed and forgotten.

\section{Bibliography}

Amico Giovanni Biagio, Larchitetto prattico in cui con facilità si danno le regole per apprendere l'architettura civile (Palermo, Nella Stamperia di Angelo Felicella: 1750; reprint, Palermo: 1997).

Aricò N., et alii, Abitare a Palermo. Due Palazzi e la loro storia tra Cinquecento e Ottocento (Cinisello Balsamo: 1983).

Boscarino S., Sicilia barocca. Architettura e città 1610-1760 (Palermo: 1981).

Calvi G. (ed.), Barocco al femminile (Rome - Bari: 1992).

Campbell E.J. - Miller S.R. - Consavari E.C., The Early Modern Italian Domestic Interior, 1400-1700: Objects, Spaces, Domesticities (Farnham: 2013).

Cancila R., Autorità sovrana e potere feudale nella Sicilia moderna (Palermo: 2013).

Cavallo S. - Evangelisti S. (eds.), Domestic Institutional Interiors in Early Modern Europe (Aldershot and Burlington VT: 2009).

Corry M. - Howard D. - Laven M. (eds.), Madonnas \& Miracles. The Holy Home in Renaissance Italy (London: 2017).

Coster W. - Spicer A. (eds.), Sacred Space in Early Modern Europe (Cambridge: 2005).

Denzinger H. - Hünermann P., Enchiridion symbolorum, definitionum et declarationum de rebus fidei et morum (Wirceburgi: 1854).

De Vio Ignazio, Li giorni d'oro di Palermo nella trionfale solennità di Santa Rosalia, vergine palermitana celebrata l'anno 1693 (Palermo, Pietro Coppula: 1694).

di Missanello Calisto, Regola e Costituzioni, Essercitij Spirituali, e Cerimonie da osservarsi nelle Congregazioni, e nelle Compagnie del Santissimo Rosario (Naples, Francesco Savio Stampatore della Corte Arcivescovale: 1647). 
Gattico Joannes Baptista, De Oratoriis domesticis et de usu altaris portatilis (Rome, Typographia Generosi Salomoni: 1746).

Grasso S., "Il Palazzo Butera a Palermo: acquisizioni documentarie", Antichità Viva 12, 5 (1980) 33-38.

Isgrò G., Feste barocche a Palermo (Palermo: 1981-86).

Ligresti D., "Per un'interpretazione del Seicento siciliano", Cheiron 17-18 (1992) 81-105.

Marafon Pecoraro M. - Palazzotto P. - Vesco M., Palazzo Alliata di Pietratagliata tra tardogotico e neostili. Archivi, cantieri, protagonisti a Palermo (Palermo: 2013).

Mattox P.E. "Domestic Sacral Space in the Florentine Renaissance Palace", Renaissance Studies 20, 5 (2006) 658-673.

Mazzè A. (ed.), I Palazzi regi di Palermo, monasteri e cappelle private (Palermo: 1991).

Mazzè A. (ed.), Processioni di Palermo sacre e profane (Palermo: 1989).

Morse M.A., The Arts of Domestic Devotion in Renaissance Italy: The Case of Venice, Ph.D. dissertation (University of Maryland: 2006).

Piazza S., Architettura e nobiltà. I palazzi del Settecento a Palermo (Palermo: 2005).

Piazza S., Dimore feudali in Sicilia fra Seicento e Settecento (Palermo: 2005).

Piazza S., Le ville di Palermo. Le dimore extraurbane dei baroni del Regno di Sicilia (14121812) (Rome: 2011).

Piazza S., "Il sistema delle residenze nobiliari", in Atlante tematico del Barocco in Italia, vol. 3: Fagiolo M. (ed.), Il sistema delle residenze nobiliari. Italia Meridionale (Rome: 2010) 304-316.

Savagnone G., Concili e sinodi di Sicilia (Palermo: 1910).

Scaduto F., Architettura e committenza nella Palermo del Cinquecento: il Palazzo Castrone di via Toledo (Palermo: 2002).

Scalisi L., Il controllo del sacro. Poteri ed istituzioni concorrenti nella Palermo del Cinque e Seicento (Rome: 2004).

Simoncini G. (ed.), L'uso dello spazio privato nell'età dell'Illuminismo, vol. 2 (Firenze: 1995).

Stabile F.M., "La Parrocchia della Bagaria. Dallo spazio del Principe al patronato municipale (1708-1858)", in Scaduto R. - Stabile F.M. (eds.), Le acque del Salvatore nel villaggio di delizie della Bagaria, Proceedings of the conference held in Bagheria on 13rd February 2009 (Palermo: 2010) 21-73.

Vitale Pietro, Il secolo d'oro aperto a Palermo dalla preziosissima inventione del corpo di S. Rosalia vergine palermitana (Palermo, s.n..: 1724; reprint, Palermo: 1824).

Waddy P., Seventeenth-century Roman Palaces: Use and the Art of the Plan (New York and Cambridge: 1990).

Zalapì A., "La lunga genesi di Palazzo Comitini" in Zalapì A. - Rotolo M. (eds.), Palazzo Comitini (Palermo: 2011) 37-136. 